DOI: https://doi.org/10.18371/fp.4(36).2019.190235

JEL Classification E49, O1, P49

\title{
THE MULTIFACETED NATURE OF THE IMPACT OF DIGITAL TECHNOLOGY ON THE ECONOMY OF TERROR
}

\author{
PANTIELIEIEVA Nataliia \\ Dr.Sc. in Economics, PhD in Technical sciences, Assoc. Prof., \\ Banking University, Cherkasy Institute \\ ORCID ID: https://orcid.org/0000-0001-6457-6912 \\ e-mail:nnpanteleeva2017@gmail.com
}

\author{
REVERA Evheniy \\ student, Banking University, Cherkasy Institute \\ e-mail: evheniy.revera@gmail.com
}

\begin{abstract}
The article deals with the characteristic features of modern terrorism, determines the impact of terrorism on economic activity, investigates the theoretical foundations of the economy of terror. The importance of digital technologies for economic development is substantiated. The essence is revealed and it is proved that the potential of digital technologies is multi-faceted. The authors determine the ability of the potential properties of digital technology, along with stimulating economic growth and prosperity, to produce risks of use for terrorist purposes and terrorist financing, which requires the implementation of certain measures to identify them and ensure effective counteraction to the illegitimate use of digital technologies.
\end{abstract}

Keywords: economy, digital economy, innovations, digital technologies, cryptocurrency, artificial intelligence, economics of terror, terrorist financing.

Introduction. Developing economic policy, countries of the world, first and
Аннотация. B cmaтье выявлень характерные признаки современного терроризма, определено влияние терроризма на экономическую деятельность, исследованы теоретические основы экономики террора. Обоснована значимость циирровых технологий для экономического развития. Раскрыта сущность и доказано, что потенщиал ичифровых технологий имеет полиаспектное характер. Определена способность потенциальных свойств циифровых технологии, наряду со стимулированием экономического роста и благосостояния, производить риски использования для террористических иелей и финансирования терроризма, что требует проведения определенных мероприятий их идентификачии и обеспечения эффективного противодействия нелигитивному использованию изифровых технологий.

Ключевые слова: экономика, иифровая экономика, инновации, ичифровые технологии, криптовалюта, искусственный интеллект, экономика террора, финансирования терроризма.

foremost, rely on scientific and technological progress and innovative moderni- 
zation of the real sector, take into account political instability, cyclicality and risks of economic crisis phenomena, growth of the shadow economy, predict the impact of these trends on the sustainable development of industries and the economy as a whole. But in recent times, they have to enter into a global war on terror and focus on the spread of the phenomenon of the economy of terror, since its effects and consequences are devastating, causing significant economic damage, limiting the opportunities that the 21 st century opens, posing threats to security and interest of the states, society and individuals. At the same time, the evolution of modern-day terrorism is directly linked to the innovation of forms of organization, strategies and tactics, as well as the development of digital technologies. The spread of modern terrorism is impossible without information and technological support, recruiting and considerable financial support. Therefore, the multifaceted nature of existing and promising information and digital technologies, namely, along with the positive effects, their ability to generate new threats and vulnerabilities, in particular cybercrime, cyberterrorism, requires further study and development of effective counter mechanisms.

Literature Review and Problem Statement. Modern terrorism has been the subject of many scientific studies by foreign and domestic scientists, in particular: the identification of terrorism as an aggressive war (M. Bassiouni, J. Baudrillard, A. Robert, etc.); distribution in the global world (I. Gobozov, O. Kilievich, Y. Kosov, B. Martynenko, D. Raschivalov, J. Stiglitz, etc.); influence on transformation processes, international and national security (M. Ayyub, M. Bazhanov, Y. Kondratiev, V. Lipkan, O. Reznikova, M. Shpura, M. Strimskaya, O. Vevera, V. Yashchenko, etc.); social origins and consequences, self-development and self-protection of the individual in the conditions of digitization and increasing level of terrorism (M. Andreev, K. Feofanov, F. Fukuyama, L. Kazmirenko, M. Kastels, V. Vitiuk, etc.); development of methods and means of preventing terrorism and counterterrorism (J. Adam, V. Antipenko, D. Bell, M. Bunchuk, M. Danylenko, V. Lyashenko, V. Mayboroda, O. Nikolaenko, V. Ustinov, etc.); terrorist financing, detection methods and counteraction mechanisms (A. Acharya, Zh. - C. Brissard, S. Dmitrov, M. Freeman, S. Grachov, J. Khaminskii, M. Levitt, J. Vittori, etc.). Despite the breadth of problematic areas, the global nature of modern terrorism, the growth of the economy of terror and the use of financial systems to finance terrorism, increased migration processes, the proliferation of digitization processes indicate the relevance and need for further research.

The purpose of the research is to investigate the prerequisites for the emergence of the economy of terror, to identify the destructive use of digital technologies, in particular cryptocurrency, for terrorist purposes.

Results of the Research. The study of the prerequisites for the emergence of the economy of terror requires an understanding of the specifics of modern terrorism, which are sufficiently covered in the scientific works of A.Yu. Pinchuk, who relying on a comparative analysis of different scientific approaches, argues that the phenomenon of modern terrorism 
"... is not the result of the deviation of human activity or accidental manifestation. It is a process that almost always begins without violence or terrorist activ- ity, but, gaining momentum, intercepts or generates extremist methods" [1, c.399] (Table 1).

Significant characteristics of modern terrorism

\begin{tabular}{|c|c|}
\hline Characteristic & A characteristic feature \\
\hline prerequisites & $\begin{array}{l}\text { globalization; change of technological way; development of information and } \\
\text { communication and digital technologies; evolution of socio-economic systems; } \\
\text { resource and trade wars; confrontation and conflict of interest; competition of } \\
\text { value models, etc. }\end{array}$ \\
\hline ideology & $\begin{array}{l}\text { opposition to modern liberal ideology; radical ideas, values and attitudes of val- } \\
\text { ue-civilizational confrontation based on political and ideological concept, reli- } \\
\text { gious and / or social-civilizational approaches, using different forms and meth- } \\
\text { ods of violence }\end{array}$ \\
\hline strategy & $\begin{array}{l}\text { exploit social tensions, alienation and distrust of the authorities, aimed mainly at } \\
\text { indirect effects }\end{array}$ \\
\hline purposefulness & $\begin{array}{l}\text { the spread of fear, tension and animosity at the level of different layers and mas- } \\
\text { sively in the society, the desire for publicity, gaining public resonance and polit- } \\
\text { ical reaction }\end{array}$ \\
\hline $\begin{array}{l}\text { organizational } \\
\text { structure }\end{array}$ & hierarchical or network models at the local and / or global levels \\
\hline $\begin{array}{l}\text { types of manifes- } \\
\text { tation }\end{array}$ & state, nuclear, religious terrorism, cyberterrorism \\
\hline $\begin{array}{l}\text { forms, methods } \\
\text { and tools }\end{array}$ & $\begin{array}{l}\text { changing the role and place of political violence; the spread of destructive inde- } \\
\text { pendent and with new social nature phenomena (diversions, insurgencies, re- } \\
\text { pression, threats, criminal acts, etc.) }\end{array}$ \\
\hline
\end{tabular}

Source: formed by the authors on the basis of $[1,2]$

Among the important issues being investigated, particular attention is paid to defining the link between terrorism and the economy, both in terms of the determinants that give rise to it (e.g., economic degradation, failures of socioeconomic policies, unemployment, loss of socio-economic status, etc.), and macroeconomic effects, caused by it (threats, devastating effects and negative impacts), for example, in terms of rates and level of economic growth, GDP, foreign investment attraction, stock market, productivity and economic efficiency, profitability, etc.

Modern terrorism is viewed in conjunction with the legal and as part of a shadow economy, which identified the need to consolidate efforts to combat it, monitor terrorist activity, in particular, using the Global Terrorism Index (GTI), which takes into account the number of terrorists, victims, the level of material damage. Thus, in 2019, countries with a very high level of terrorism and leading the ranking was Afghanistan (9.6), Iraq (9.24), Nigeria (8.59), Syria (8). Ukraine was ranked 24th in the rating of 5,547, improving its position by 3 points, US was ranked 22nd $(5,69)$ and UK - 28th $(5,405)[3, p .8]$.

The economic impact of terrorism on the global economy, determined by the level of losses, was $\$ 33$ billion in 2018, the maximum in 2014 ( $\$ 111$ billion), and the minimum in 2000 (\$9 billion). No country suffered more than $5 \%$ of GDP, with the exception of Afghanistan 
(19.4\% of GDP) [3, p.29]. In the regional aspect, Africa (sub-Saharan Africa), the Middle East and North Africa suffered the largest losses, $\$ 12.17$ billion and $37 \%$ of the global level, and $\$ 11.9$ billion and 36\% respectively, Europe - 0.6 billion US \$ and $2 \%$, and the smallest losses was in Central America and the Caribbean ( $\$ 0.12$ billion and $0.4 \%$ ). In addition, terrorism has impacts and indirect economic costs (Table 2).

Characteristics of economic impact of modern terrorism

Table 2

\begin{tabular}{|l|l|}
\hline \multicolumn{1}{|c|}{ Object } & \multicolumn{1}{c|}{ The effect of terrorism } \\
\hline Economic growth & decrease in economic growth, decrease in per capita income \\
\hline Trade & $\begin{array}{l}\text { threats and uncertainty necessitate risk insurance and increased security, leading } \\
\text { to increased costs }\end{array}$ \\
\hline Financial markets & $\begin{array}{l}\text { are negatively impacted in the short term and continuing to function effectively in } \\
\text { the long term; developed countries are more resilient to terrorist upheaval; coun- } \\
\text { try's sovereign credit rating decreases; in the markets volatility increases and prof- } \\
\text { itability decreases; negative impact on the stock price causes investors to refocus } \\
\text { from stocks to bonds }\end{array}$ \\
\hline Tourism & $\begin{array}{l}\text { anxiety increases; an increase in the level of terrorism causes economic losses, } \\
\text { since a decrease in the number of tourists reduces the income; the level of tour- } \\
\text { ism in neighboring countries is decreasing }\end{array}$ \\
\hline $\begin{array}{l}\text { Foreign direct in- } \\
\text { vestment }\end{array}$ & decrease as a result of increased risk of investment loss \\
\hline
\end{tabular}

Source: formed by the authors on the basis of [3, p.31-33]

Therefore, according to O. S. Kuznetsova, economy of terror envisages "production, distribution and consumption of various goods, works, services for the financial support of terrorist organizations", as well as ".. has ... a system of stable and regular economic relations, relevant institutions, innovative technologies" [4, p.11]. This view is supported by V.V. Kaftan [5, p.25], stating that the economy of terror exists in parallel with the legal economy, operates through the network created in it on the basis of legal economic institutions, which provides direct or indirect support to the subjects of terrorist activity.

Consider the phenomenon of the economy of terror as an independent economic system from the standpoint of concepts of economic theory and relations. Thus, by subject-object nature, the economy of terror is formed at the ex- pense of economic activity and relations of specific organizations (entities of terrorist activity), which by their functional and organizational structure can be perceived in the same way as any international or national company or a corporation. Then, the issue of primary capital and sources of funding is quite natural. Analyzing the practice of terrorist financing, Yu.V. Latov summarizes the following models and sources of income: 1) administratively institutionalized "gray area" (territories of internationally recognized countries that are not controlled or controlled in part by the legal government) - theft of resources, drug smuggling; 2) guerrilla "gray zone" - smuggling of drugs and other goods, "taxes" on the population; 3) an underground organization with strong external links sponsorship of the Diaspora, humanitarian aid societies, and religious organiza- 
tions; 4) an underground organization with weak external links - local shadow economy [6].

The subject of the economy of terror is the terrorist "service" (terrorist act), which has an impact on the legal economy. The main function of the economy of terror is to ensure the production of such "service". It is destructive and counterproductive with direct or delayed effects. The production process is rational in the choice of purpose, resources and methods, subject to certain constraints not only on capital, material and production resources, but also the institutional capacity and counteracting power of the governmental structures of the countries of the world, which increases costs and / or reduces the profitability of entities of the economy of terror. At the same time, the effects include direct material losses, increased stock market volatility, the undermining of financial stability and the challenge of crisis, the redistribution of functions between industries, etc. A separate issue is the taxation in the economy of terror, to which J. Brauer and H. van Tuil expressed their own point of view [7, p.793-496].

The economy of terror, like the legal economy, is equally positive about innovation, but due to their multifaceted nature, different functionalities are used, directing them, firstly, to the benefit of their own subjects of terrorist activity, and secondly, to the benefit of society.

The manifestation of a multi-aspect nature is most demonstrated by digital technologies [8, 9]. The revolutionary trend is certainly the emergence of cryptocurrencies, their rapid expansion in the financial market and the formation of a separate segment (cryptocurrency mar- ket), the existence of which arouses ambiguous position / debate both in both subject matter and legitimacy. The innovative potential and characteristics of cryptocurrencies are sufficiently covered in $[10,11]$. E.V. Salnikov emphasizes: "the innovative nature of cryptocurrency is that it offers a qualitatively new model of movement of financial flows in terror" $[12$, p. 5], at the same time, "the innovative nature of the cryptocurrency renders meaningless all previous measures to combat the financing of terrorist organizations and groups by governments and international organizations" $[12, \mathrm{p} .6]$. This is due not only to the functional nature, but also to the long-term uncertainty of the legal status, the limits of use, the procedure for taxation of cryptocurrencies in many countries, including Ukraine. In our view, this is a consequence of the fear of losing the hegemony of national currencies and the ability of cryptocurrencies to function as world money. Therefore, probably, the cryptocurrency was declared a threat to national security by governments and the FATF. Along with its legitimate use to increase the efficiency of payments, micropayments and monetization of the sale of goods and services via the Internet, the promotion of international money transfers, as well as the expansion of financial services inclusion and development of innovative financial products and services based on it, the potential risks of illegal use of cryptocurrency for the purpose of money laundering and terrorist financing are increasing at the expense of its functional features, uncertain legal status and lack of regulation. Potential areas of application of cryptocurrencies in the economy of terror are: legalization 
of proceeds of crime through investing in cryptocurrency; accumulation of money in cryptocurrency with resale abroad; covert financing of terrorist and extremist activities; trafficking in illicit substances and weapons; corruption [13].

Another digital technology that has significant potential and a multi-faceted nature of use is artificial intelligence (computerized information processing system with machine learning elements, new data processing algorithms). Artificial intelligence with Big Data analytics, are already being actively implemented in financial intermediaries' activity, transforming the entire financial sector, enabling to take operational and analytical tasks to the next level, manage capital, loyalty programs and offer personalized banking services and investment models, transform business models and conduct anti-crisis measures, make payments and remittances, credit scoring, financial trading and monitoring, compliance control and more. At the same time, it is quite natural to identify potential threats to the use the artificial intelligence in the economy of terror [14]. This aspect should be considered, on the one hand, at the level of the subjects of terrorist activity and their practices, and on the other hand, on the use of the capabilities and innovations of artificial intelligence to combat and finance terrorism. Without overburdening the discussion with factual material, it should be noted that artificial intelligence allows to accelerate the processing of information and to better perform: 1) analysis and counteraction of content on the global Internet and social networks that have characteristics and are aimed at terrorist aims [15]; 2) identification of transboundary movements of terrorists and their location in public places and at strategically important objects; 3) financial monitoring of the economic relations of the entities to identify companies and individuals financing the terrorism; 4) identification of typical and innovative terrorist financing schemes [16]; 5) monitoring and forecasting of infrastructure, its protection against cyberattacks, including cryptocurrency; etc.

Conclusion. Therefore, the potential of digital technologies is multifaceted. They can stimulate the economic growth and well-being of the society, provided the chosen strategic guidelines, tactics and pace of implementation of projects, legal maturity and infrastructural readiness, digital convergence in all spheres of public life. However, the existence of a phenomenon such as the economy of terror indicates that there are risks of using the potential properties of digital technology for terrorist purposes and terrorist financing. This, in turn, requires the consolidation of efforts to identify risks and ensure effective counteraction to the illegal use of digital technologies. 


\section{References}

1. Pinchuk, A.Ju. K probleme ponimanija sushhnosti i specifika mezhdunarodnogo terrorizma $\mathrm{v}$ sovremennom mire [The problem of understanding the nature and specificity of international terrorism in the modern world]. Retrieved from: https://cyberleninka.ru/article/n/k-probleme-ponimaniya-suschnosti-i-spetsifikamezhdunarodnogo-terrorizma-v-sovremennom-mire [in Russian].

2. Pinchuk, A. Ju. Sovremennyj mezhdunarodnyj terrorizm kak aktual'naja politicheskaja problema global'nogo razvitija [Modern international terrorism as an actual political problem of global development]. Retrieved from: https://cyberleninka.ru/article/n/sovremennyy-mezhdunarodnyy-terrorizm-kakaktualnaya-politicheskaya-problema-globalnogo-razvitiya [in Russian].

3. Institute for Economics \& Peace. Global Terrorism Index 2019: Measuring the Impact of Terrorism, Sydney, November 2019. Retrieved from: http://visionofhumanity.org/reports.

4. Kuznecova, O.S. Razvitie institutov protivodejstvija jekonomicheskim osnovam mezhdunarodnogo terrorizma $\mathrm{v}$ sisteme obespechenija jekonomicheskoj bezopasnosti. [Development of institutions to counteract the economic foundations of international terrorism in the system of economic security]. Retrieved from: https://www.dissercat.com/content/razvitie-institutov-protivodeistviyaekonomicheskim-osnovam-mezhdunarodnogo-terrorizma-v-sis [in Russian].

5. Kaftan, V.V. (2014). Finansovo-jekonomicheskie osnovanija sovremennogo terrorizma. [Financial and economic foundations of modern terrorism]. Gumanitarnye nauki. Vestnik Finansovogo universiteta - Humanities. Financial University Gazette, 1 (13), 22-27 [in Russian].

6. Latov, Ju. V. (2007). Jekonomicheskij analiz terrorizma. [Economic Analysis of Terrorism]. Obshhestvennye nauki i sovremennost' - Social Sciences and Modernity, 5, 28-45 [in Russian].

7. Zamki, bitvy i bomby. Kak jekonomika ob\#jasnjaet voennuju istoriju [Castles, battles and bombs. How the economy explains military history]. (2016). [M. Rudakova, D. Shestakov Trans.] [in Russian].

8. Pantielieieva, N., Zaporozhets, S., Nagaichuk, N. \& Bartosh, O. (2019). Transformation of financial intermediation in the context of spread of digital trends. 
Bulletin of the National Academy of Sciences of the Republic of Kazakhstan, 3, 144152. doi: 10.32014/2019.2518-1467.81.

9. Pantielieieva, N., Khutorna, M., Lytvynenko, O., Potapenko, L. (2019). FinTech, RegTech and Traditional Financial Inter-mediation: Trends and Threats for Financial Stability. Data-Centric Business and Applications: Evolvements in Business Information Processing and Management (Volume 3), Springer, 1-21 doi: 10.1007/978-3-030-35649-1.

10. Pantielieieva, N.M. (2015). Novi formy groshej $\mathrm{v}$ umovah formuvannja informacijnogo suspil'stva. [New forms of money in the conditions of formation of information society]. Visnyk NBU - Bulletin of the National Bank of Ukraine, 5 (traven'), 25-31 [in Ukrainian].

11. Pantielieieva, N.M. (2017). Innovacijnyj potencial i harakterystychni osoblyvosti mehanizmu zaluchennja finansuvannja $\mathrm{v}$ novi tehnologichni proekty shljahom vypusku i prodazhu novyh kryptovaljut uchasnykam rynku [Innovative potential and characteristics of the mechanism of attraction of financing in new technological projects by issuing and selling new cryptocurrencies to market participants]. Zbirnyk materialiv mizhnarodnoi' naukovo-praktychnoi' konferencii': Novi formy groshej ta finansovyh aktyviv: stanovlennja, perspektyvy, ryzyky - Proceedings of the Internation Scientific and Practical Conference: New forms of money and financial assets: formation, prospects, risks (pp. 153-158) [in Ukrainian].

12. Sal'nikov, E.V. \& Sal'nikova, I.N. (2016). Kriptovaljuta kak innovacija jekonomiki terrora. [Cryptocurrency as an innovation of the terror economy]. Internet-zhurnal «NAUKOVEDENIE» - Internet Journal "EDUCATION", 8, 3. Retrieved from: http://naukovedenie.ru/PDF/86EVN316.pdf [in Russian].

13. Virtual'nye valjuty Kljuchevye opredelenija i potencial'nye riski v sfere POD/FT. [Virtual currencies Key definitions and potential risks in AML / CFT]. Retrieved from: https://eurasiangroup.org/files/FATF_docs/ Virtualnye_valyuty_FATF_ 2014.pdf [in Russian].

14. V Minske obsuzhdajut vozmozhnosti novyh tehnologij i iskusstvennogo intellekta $\mathrm{v}$ bor'be s terrorizmom. [Possibilities of new technologies and artificial intelligence in the fight against terrorism are discussed in Minsk]. Retrieved from: https://news.un.org/ru/story/ 2019/09/1362292 [in Russian]. 
15. Problemy ispol'zovanija iskusstvennogo intellekta $\mathrm{v}$ bor'be $\mathrm{s}$ terrorizmom $\mathrm{v}$ social'nyh setjah. [Problems of using artificial intelligence in the fight against terrorism in social networks]. Retrieved from: https://hype.ru/@id3153/problemyispolzovaniya-iskusstvennogo-intellekta-v-borbe-s-terrorizmom-v-socialnyh-setyahrn4lh717 [in Russian].

16. Aktual'ni metodi, sposobi ta finansovi instrumenti finansuvannja terorizmu ta separatizmu [Current methods, methods and financial instruments for financing terrorism and separatism]. Retrieved from: http://www.sdfm.gov.ua/content/file/Site_docs/2014/20141229/tipolog2014.pdf [in Ukrainian]. 